\section{Fla. 7771, a Medium-large, Heat- tolerant, Jointless-pedicel Tomato}

\author{
J.W. Scott ${ }^{1}$ \\ Gulf Coast Research and Education Center, University of Florida, 5007 60th \\ Street East, Bradenton, FL 34203
}

Additional index words. fruit set, Lycopersicon esculentum, cultivar

Fla. 7771 is a medium- to large-fruited, jointless-pedicel, fresh-market tomato (Lycopersicon esculentum Mill.) breeding line that sets fruit well under the high temperature $\left(>32^{\circ} \mathrm{C}\right.$ day $/>21^{\circ} \mathrm{C}$ night $)$, high humidity conditions prevalent in Florida during the summer and fall. Combining heat tolerance, jointless pedicels, and large fruit size without numerous fruit defects has been difficult to achieve. Fla. 7771 should be useful to tomato breeders as a parent to produce jointless, heat-tolerant hybrid cultivars (Scott et al., 1997) and in developing improved heat-tolerant inbreds.

\section{Origin}

Fla. 7771 is the first release from a breeding project, spanning 18 years, designed to develop large-fruited, heat-tolerant, jointless breeding lines. The pedigree is complex and involves numerous crosses (Fig. 1). Seed was increased in the $\mathrm{F}_{7}$ generation after a cross between Fla. 7546B and an $\mathrm{F}_{7}$ derived from a cross between Fla. 7340 and Fla. 7319. Both parents in the final cross were jointless and heat-tolerant, with most of the heat tolerance coming from Fla. 7340 in both cases. Fla. 7340 was derived from a jointless $F_{7}$ with heat tolerance tracing back to $\mathrm{Cl} 123$ (VC8-1-2-1), a breeding line from the Asian Vegetable Research and Development Center (AVRDC) in Taiwan. 'Burgis' (Augustine et al., 1981c) was the source of jointlessness. The $\mathrm{F}_{3}$ parent of Fla. 7340 was a jointed, heat-tolerant line with heat tolerance tracing to C-28 (Campbell 28), a major source of heat tolerance in the Univ. of Florida breeding program. Fla. 7182 is a heat-sensitive, jointless inbred derived from 'Horizon' (Scott et al., 1985a) and Fla. 7095, another jointless inbred. The pedigrees of Fla. 1B and 1C have been previously described (Augustine et al., 1981b) and the backgrounds of 6120 and 648 are described by Scott et al. (1985b). Fla. 7060 was the very large fruited parent of 'Solar Set' (Scott et al., 1989). Fla. 7319 is a heat-sensitive, jointless

Received for publication 19 July 1999. Accepted for publication 14 Dec. 1999. Florida Agricultural Experiment Station Journal Series No. R-06987. I thank Karen Pearce and Jan Watson for their excellent technical support. The cost of publishing this paper was defrayed in part by the payment of page charges. Under postal regulations, this paper therefore must be hereby marked advertisement solely to indicate this fact.

${ }^{1}$ E-mail address: jwsc@gnv.ifas.ufl.edu inbred derived from the cross of $\mathrm{F}_{5}$ and $\mathrm{F}_{7}$ parents. The jointed $\mathrm{F}_{5}$ parent was derived from 'Suncoast' (Scott et al., 1985b), 'Hayslip' (Augustine et al., 1981a), and EO3. EO3 is a jointless inbred with a complex pedigree involving cold-tolerant European breeding lines and greenhouse inbreds from Ohio and Ontario, Canada, including 'Vendor'. The $\mathrm{F}_{7}$ parent of
Fla. 7319 carries the jointless trait, which was derived from 'Horizon'.

\section{Description}

Fla. 7771 has a determinate $(s p)$ vine that provides adequate fruit cover. The leaves are somewhat erect rather than being pendant as in most cultivars. The jointless pedicel is conferred by the $j-2$ gene. Fruit shoulders are light green $(u g)$. In recent trials, the medium-tolarge fruit were similar in size to those of the Florida-grown cultivars Equinox, Agriset 761, Colonial, and Sanibel (Tables 1, 2). 'Sanibel' and 'Colonial' are jointless cultivars. Maturity in the fall is early under high temperature conditions and early to mid-season in the spring. In the summers of 1997 and 1998, early yields of Fla. 7771 were similar to those of the earliest cultigens evaluated and significantly higher than those of the heat-sensitive controls (Table 1). In Spring 1998, Fla. 7771 was not as

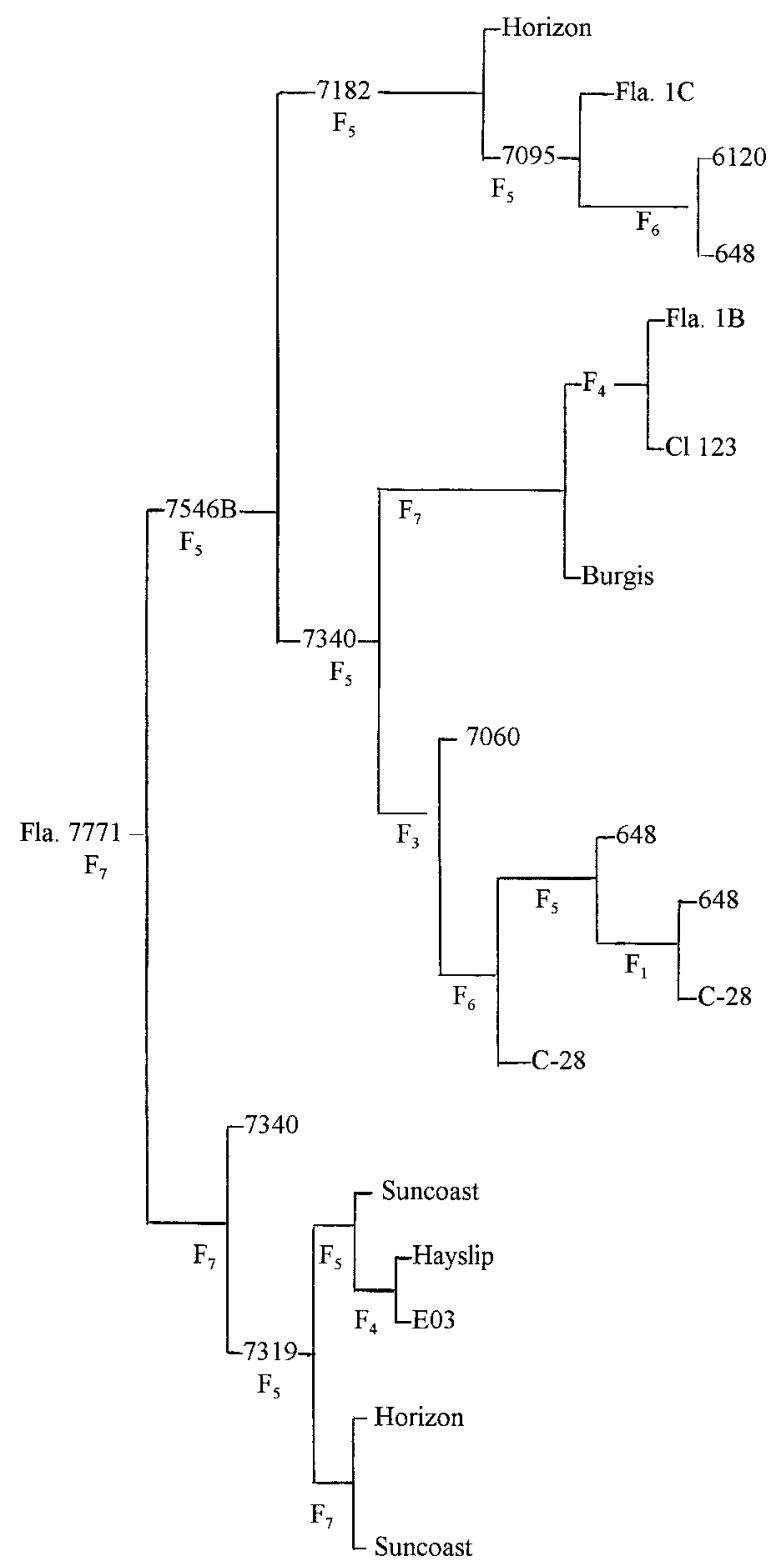

Fig. 1. Pedigree of Fla. 7771. All 7000 numbers should have the prefix Fla. 
Table 1. Marketable yield, fruit weight, and percentage of culls for tomato cultigens grown under high temperature conditions at Bradenton, Fla., in 1997 and 1998.

\begin{tabular}{|c|c|c|c|c|c|c|c|c|}
\hline \multirow[b]{3}{*}{ Cultigen $^{z}$} & \multicolumn{4}{|c|}{ Summer 1997} & \multicolumn{4}{|c|}{ Summer 1998} \\
\hline & \multicolumn{2}{|c|}{$\begin{array}{c}\text { Marketable yieldy } \\
\text { (kg/plant) }\end{array}$} & \multirow{2}{*}{$\begin{array}{c}\text { Fruit } \\
\text { size } \\
\text { (g/fruit) }\end{array}$} & \multirow{2}{*}{$\begin{array}{c}\text { Culls } \\
(\%)\end{array}$} & \multicolumn{2}{|c|}{$\begin{array}{l}\text { Marketable yield } \\
(\mathrm{kg} / \text { plant })\end{array}$} & \multirow{2}{*}{$\begin{array}{c}\text { Fruit } \\
\text { size } \\
\text { (g/fruit) }\end{array}$} & \multirow{2}{*}{$\begin{array}{r}\text { Culls } \\
(\%)\end{array}$} \\
\hline & Early & Total & & & Early & Total & & \\
\hline Fla. 7771 & $1.41 \mathrm{a}-\mathrm{c}^{\mathrm{x}}$ & $2.36 \mathrm{ab}$ & $141 \mathrm{ab}$ & 31 & $1.28 \mathrm{a}$ & $2.35 \mathrm{a}$ & $139 a b$ & $23 \mathrm{~b}$ \\
\hline Equinox & $0.81 \mathrm{~cd}$ & $1.43 \mathrm{ab}$ & $138 \mathrm{ab}$ & 40 & $1.35 \mathrm{a}$ & $2.18 \mathrm{a}$ & $147 \mathrm{a}$ & $28 \mathrm{~b}$ \\
\hline Fla. 7718 & $1.83 \mathrm{ab}$ & $2.72 \mathrm{a}$ & $139 \mathrm{ab}$ & 20 & $1.16 \mathrm{a}$ & $1.93 \mathrm{a}$ & $130 \mathrm{~cd}$ & $23 \mathrm{~b}$ \\
\hline Fla. 7324 & $1.31 \mathrm{bc}$ & $1.83 \mathrm{ab}$ & $111 \mathrm{~b}$ & 36 & $1.02 \mathrm{a}$ & $1.82 \mathrm{a}$ & $119 \mathrm{~d}$ & $32 \mathrm{~b}$ \\
\hline Fla. 7719 & $2.21 \mathrm{a}$ & $2.91 \mathrm{a}$ & $134 a b$ & 24 & $0.92 \mathrm{ab}$ & $1.64 \mathrm{a}$ & $125 \mathrm{~cd}$ & $30 \mathrm{~b}$ \\
\hline Agriset 761 & --- & --- & --- & --- & $0.24 \mathrm{~b}$ & $0.42 \mathrm{~b}$ & $133 b c$ & $73 \mathrm{a}$ \\
\hline Sanibel & --- & --- & --- & --- & $0.12 \mathrm{~b}$ & $0.51 \mathrm{~b}$ & $133 b c$ & $60 \mathrm{a}$ \\
\hline Colonial & $0.20 \mathrm{~d}$ & $0.87 \mathrm{~b}$ & $147 \mathrm{a}$ & 41 & --- & --- & --- & --- \\
\hline
\end{tabular}

${ }^{2}$ Fla. 7771, Equinox, Fla. 7718, Fla. 7324, and Fla. 7719 are heat-tolerant. Fla. 7771, Sanibel, and Colonial have jointless pedicels; the others have jointed pedicels.

${ }^{y}$ Fruit harvested at breaker stage or beyond three times at weekly intervals, early harvest was the sum of the first two harvests.

${ }^{x}$ Mean separation within columns by Duncan's multiple range test at $P \leq 0.05$.

early as 'Equinox' or Fla. 7324, the heattolerant parent of 'Equinox', but was earlier than each of the other (heat-sensitive) cultigens (Table 2). The percentage of cull fruit was relatively low in the spring and summer trials (Tables 1,2). Blossom scars have a nipple similar to or the same as $n$-2 (Barten et al., 1994), which provides very good smoothness. Total yields of Fla. 7771 were consistent in the summers of 1997 and 1998. They were similar to those of the other heat-tolerant cultigens evaluated and were significantly greater than the yields of the heat-sensitive cultivars Agriset 761, Sanibel, or Colonial (Table 1). In Spring 1998, total yield of Fla. 7771 was similar to that of 'Equinox' and greater than that of the other cultigens (Table 2). Fla. 7771 has also performed well in north (Quincy) and south (Homestead) Florida (data not shown).

Observations over several seasons and locations indicate that fruit firmness is only medium, although fruit deformation was similar to that of Florida-grown cultivars Agriset 761 and Sanibel in Spring 1998 (Table 2). For commercial hybridization, crosses should be made with firm parents to ensure adequate firmness for shipping. Fruit color has been acceptable over many seasons of testing. In Spring 1998, L and a scores for external color were not significantly different from those of 'Sanibel' and 'Agriset 761', while the b score was similar to that of 'Sanibel' but greater than that of 'Agriset 761'. The L, a, and b scores for internal color were similar to those of 'Sanibel'. The L score was similar to that of 'Agriset 761' while the $\mathrm{a}$ and $\mathrm{b}$ scores were higher. The relatively high $\mathrm{L}$ scores indicate that Fla. 7771 fruit tend to be darker than many cultigens. The internal a scores were lower than those of some of the cultigens, indicating a less intense red color, whereas the external and internal $b$ scores were higher, indicating a higher yellow color. The fruit color of Fla. 7771 is acceptable, but not a deep red. J.W. Scott and a technician have rated flavor of Fla. 7771 a 3 on a scale of 1 to 5 , where 1 is poor, 3 is acceptable, and 5 is excellent. The acidity of the fruit is stronger than the sweetness.

\section{Disease resistance}

Fla. 7771 is resistant to races 1 and 2 of Fusarium wilt [Fusarium oxysporum Schlechtend. f. sp. lycopersici (Sacc.) Snyder and Hansen] $(I, I-2)$ and gray leafspot Stemphyllium solani Weber) (Sm). Fla. 7771 is tolerant of most fruit disorders. It may have some susceptibility to puffiness, although none has been noted since 1997 and then it was of minor importance. Only a minor amount of radial cracking of red fruit has occurred.

\section{Availability}

Fla. 7771 is an open-pollinated (pure line) release. Distribution of seed is through the Florida Foundation Seed Producers, P.O. Box 309, Greenwood, FL 32443. Small amounts of seed for research purposes are also available from the author.

\section{Literature Cited}

Augustine, J.J., R.B. Volin, H.H. Bryan, P.H.Everett, D.S. Burgis, and D.D. Gull. 1981a. Hayslip, a jointless fresh-market tomato. Florida Agr. Expt. Sta. Circ. S-278.

Augustine, J.J., R.B. Volin, D.S. Burgis, P.H. Everett, N.C. Hayslip, H.H. Bryan, D.D. Gull, and J.P. Crill. 1981b. Florida 1A, Florida 1B, Florida 1C, three jointed fresh-market tomato selections of Florida 1 resistant to race 1 and 2 of Fusarium wilt and Verticillium wilt. Florida Agr. Expt. Sta. Circ. S-282.

Augustine J.J., R.B. Volin, P.H. Everett, H.H. Bryan, N.C. Hayslip, D.D. Gull, and J.P. Crill. 1981c. Burgis, a jointless uniform green-fruited freshmarket tomato. Florida Agr. Expt. Sta. Circ. S-279.

Barten, J.H.N., J.W. Scott, and R.G. Gardner. 1994. Characterization of blossom-end morphology genes in tomato and their usefulness in breeding for smooth blossom-end scars. J. Amer. Soc. Hort. Sci. 119:798-803.

Scott, J.W., J.A. Bartz, H.H. Bryan, P.H. Everett, D.D. Gull, T.K. Howe, P.J. Stoffella, and R.B. Volin. 1985a. Horizon, a fresh market tomato with concentrated fruit set. Florida Agr. Expt. Sta. Circ. S-323.

Scott, J.W., H.H. Bryan, and L.J. Ramos. 1997. High temperature fruit setting ability of large-fruited, jointless pedicel tomato hybrids with various combinations of heat-tolerance. Proc. Florida State Hort. Soc. 110:281-284.

Scott, J.W., P.H. Everett, H.H. Bryan, D.D. Gull, T.K. Howe, P.J. Stoffella, and R.B. Volin. 1985b. Suncoast, a large-fruited home garden tomato. Florida Agr. Expt. Sta. Circ. S-322.

Scott, J.W., S.M. Olson, H.H. Bryan, T.K. Howe, P.J. Stoffella, and J.A. Bartz. 1989. Solar Set, a heat-tolerant, fresh market tomato hybrid. Florida Agr. Expt. Sta. Circ. S-359.

Table 2. Marketable yield, fruit firmness, and fruit color for tomato cultigens grown at Bradenton, Fla., in Spring 1998.

\begin{tabular}{|c|c|c|c|c|c|c|c|c|c|c|c|}
\hline \multirow[b]{3}{*}{ Cultigen } & \multirow{2}{*}{\multicolumn{2}{|c|}{$\begin{array}{c}\begin{array}{c}\text { Marketable yield } \\
\text { (kg/plant) }\end{array} \\
\end{array}$}} & \multirow{3}{*}{$\begin{array}{c}\text { Fruit } \\
\text { size } \\
\text { (g/fruit) }\end{array}$} & \multirow{3}{*}{$\begin{array}{c}\text { Culls } \\
(\%)\end{array}$} & \multirow{3}{*}{$\begin{array}{c}\text { Firmness }^{y} \\
\text { (mm de- } \\
\text { formation) }\end{array}$} & \multicolumn{6}{|c|}{ Fruit color $^{\mathrm{x}}$} \\
\hline & & & & & & \multicolumn{3}{|c|}{ External } & \multicolumn{3}{|c|}{ Internal } \\
\hline & Early & Total & & & & $\mathrm{L}$ & $\mathrm{a}$ & $\mathrm{b}$ & $\mathrm{L}$ & $\mathrm{a}$ & $\mathrm{b}$ \\
\hline Fla. 7771 & $2.48 \mathrm{~b}^{\mathrm{w}}$ & $7.90 \mathrm{a}$ & $164 \mathrm{ab}$ & $14.5 \mathrm{c}$ & $5.3 \mathrm{bc}$ & $47.1 \mathrm{a}$ & $19.5 \mathrm{~b}$ & $42.3 \mathrm{a}$ & $51.6 \mathrm{ab}$ & $18.3 \mathrm{c}$ & $31.1 \mathrm{a}$ \\
\hline Fla. 7775 & $1.65 \mathrm{~cd}$ & $6.84 \mathrm{bc}$ & $155 \mathrm{~b}$ & $15.4 \mathrm{bc}$ & $3.5 \mathrm{~d}$ & $44.7 \mathrm{bc}$ & $24.8 \mathrm{a}$ & $38.1 \mathrm{bc}$ & $48.2 \mathrm{~cd}$ & $22.2 \mathrm{a}$ & $28.3 \mathrm{~b}$ \\
\hline Fla. 7718 & $2.26 \mathrm{bc}$ & $6.73 \mathrm{bc}$ & $154 \mathrm{~b}$ & $21.9 \mathrm{a}-\mathrm{c}$ & --- & --- & --- & --- & --- & --- & --- \\
\hline Agriset 761 & $1.40 \mathrm{~d}$ & $6.31 \mathrm{~cd}$ & $159 a b$ & $25.9 \mathrm{ab}$ & $5.7 \mathrm{ab}$ & $45.3 \mathrm{ab}$ & $19.2 \mathrm{~b}$ & $38.8 \mathrm{~b}$ & $53.8 \mathrm{a}$ & $14.8 \mathrm{~d}$ & $28.6 \mathrm{~b}$ \\
\hline Sanibel & $0.59 \mathrm{e}$ & $6.19 \mathrm{~cd}$ & $179 a$ & $23.5 \mathrm{a}-\mathrm{c}$ & $4.9 c$ & $45.8 \mathrm{ab}$ & $20.8 \mathrm{~b}$ & $39.8 \mathrm{ab}$ & $48.9 \mathrm{~b}-\mathrm{d}$ & $19.5 b c$ & $30.7 \mathrm{a}$ \\
\hline
\end{tabular}

${ }^{2}$ Fruit harvested at breaker stage or beyond three times at weekly intervals; early harvest indicates first harvest.

${ }^{\mathrm{y}}$ Measured with a pressure tester with a 1-kg weight and a $1.5-\mathrm{cm}$ contact plate for $5 \mathrm{~s}$. Contact plate was placed over locules on 10 fruit per cultigen per block (3). Lower values indicate firmer fruit.

${ }^{x}$ Determined with a Minolta CR-300 Chroma Meter. External color taken in equatorial plane of fruit, internal color of each fruit was a composite of three locations; pericarp, placenta, and locule. There were 10 fruit per cultigen per block.

wMean separation within columns by Duncan's multiple range test at $P \leq 0.05$. 